\title{
Introduction: Special Issue Dedicated to Christie Davies
}

\author{
Liisi Laineste \\ Estonian Literary Museum \\ Sharon Lockyer \\ Brunel University London
}

\begin{abstract}
'Inspirational,' 'erudite,' 'pioneering,' 'versatile,' 'eccentric,' and, of course, 'witty,' are just some of the words used to describe the late Christie Davies, who was Professor Emeritus at Reading University in the United Kingdom. Christie was a pillar of humor studies and the International Society for Humor Studies (ISHS) and was a respected contributor and reviewer for HUMOR: International Journal of Humor Research. He is best-known for his work on jokes and their targets: ethnic jokes, political jokes, lawyer jokes, religious jokes, mother-inlaw jokes; for using comparative methodology and analyzing jokes as social facts; and for viewing jokes as thermometers rather than thermostats of a society - he argued jokes may be able to criticize a society, but they will not lead to societal change. He inspired humor studies students to follow his example by formulating hypotheses and creating falsifiable theories and continuing to develop ideas in the light of new information.
\end{abstract}

This Special Issue of HUMOR: International Journal of Humor Research serves to honor, and celebrate, the extensive contributions Christie made to humor studies, social sciences, academia more broadly, and beyond. Although it would be foolish to think anyone, or anything, could match Christie's intellectual prowess, our aim here has been to capture the spirit of Christie by bringing together a varied mix of contributions from his colleagues, friends and students. Furthermore, this Special Issue complements the earlier In Memoriam Special Issue of the European Journal of Humour Research (2018). There is no way to give an exhaustive insight into all aspects and ideas that Christie was famous for, nor to provide enough space to all his admires in a single special issue (and perhaps not even in a series of volumes on his work), but we hope this Special Issue gives a flavor of Christie's interests and influences.

Christie was the most well-travelled person anyone could meet, and his knowledge and expertise crossed disciplinary boundaries, therefore we have drawn together contributors from across the globe (e.g. United Kingdom, America, Japan, Italy, Poland, Greece) and from different disciplinary perspectives (e.g. folklore, sociolinguistics, linguistics, philosophy, American literature and culture, translation studies). Christie had a unique status as renowned academic, and close friend, of humor scholars, and as someone who impacted those both within and outside the academy in equal measure. To reflect this, contributions include traditional scholarly articles on topics that Christie was as expert in (Elliott Oring, Hannah Baldwin, Jan Chovanec, Dorota Brzozowska and Władysław Chłopicki, Villy Tsakona and Argiris Archakis, Holger Kersten), more personal reflections on Christie's work and influences (Delia Chiaro, Giacinto Palmieri, Goh Abe, and a group of authors representing the International Summer School for Humour Studies where Christie was a longstanding lecturer), and a bibliography of Christie's impressive and all-encompassing publications from academic articles through to arts reviews (Moira Marsh).

Christie Davies will be missed by the International Society for Humor Studies, readers of HUMOR: International Journal of Humor Research, and everyone who had the pleasure of 
meeting or working with Christie. We hope that through this Special Issue his work will continue to influence and shape humor studies and inspire future generations of humor studies scholars.

Liisi Laineste, Department of Folkloristics at the Estonian Literary Museum, Centre of Excellence in Estonian Studies (CEES), Tartu, Estonia, E-mail: $\underline{\text { liisi@ folklore.ee }}$

Sharon Lockyer, Centre for Comedy Studies Research (CCSR), Department of Social and Political Sciences, Brunel University London, UK, E-mail: Sharon.Lockyer@brunel.ac.uk

\section{Author Biographies}

Liisi Laineste is a senior researcher at the Department of Folkloristics at the Estonian Literary Museum and a member of the Centre of Excellence in Estonian Studies (CEES). Chairing the research group of contemporary culture and media at the Centre for Excellence, her current research interests include the verbal and visual components of humorous cultural communication, e.g. internet folklore (memes and their cultural contexts, intertextuality, online communication styles), digital humanities, and expressing emotion online (eg humour and hate speech). She has published a number of articles on ethnic, political and internet humour and and is the editor of several humour-related volumes, most recently co-editing The Multi-mediatized Other - The Construction of Reality in East-Central Europe 1945-1980 (with D. Demski, I. Sz Kristof, A. Kasabova and K. Baraniecka-Olszewska, L'Harmattan 2017). She has organized conferences, symposia and a summer school on humour studies. Her work on the Special Issue was supported by the Estonian Ministry of Education and Research (IUT 22-5), and by the European Union through the European Regional Development Fund (Centre of Excellence in Estonian Studies).

Sharon Lockyer is the founding director of the Centre for Comedy Studies Research (CCSR) and a Senior Lecturer in Sociology and Communications in the Department of Social and Political Sciences at Brunel University London, UK. Her research interests include critical comedy studies, identity politics and comic media representations and the sociology of popular culture. She is editor of Reading Little Britain: Comedy Matters on Contemporary Television (I.B.Tauris 2010), co-editor of Beyond a Joke: The Limits of Humour (Palgrave Macmillan 2005, 2009), Controversial Images: Media Representations on the Edge (Palgrave Macmillan 2013) and Screening the Undead: Vampires and Zombies in Film and Television (I.B.Tauris 2014) and has published in a range of academic journals. She is also the founding co-editor of the Palgrave Studies in Comedy book series. 